\title{
ANALISIS KONFLIK DALAM IMPLEMENTASI KEBIJAKAN TATA RUANG WILAYAH DI PEMBANGUNAN PARIWISATA BERKELANJUTAN DI KAWASAN GEOPARK RINJANI-LOMBOK, PROVINSI NUSA TENGGARA BARAT
}

\author{
Oleh \\ Johan Bachry \\ Institut Pemerintahan Dalam Negeri \\ Email: Johanbachry@gmail.com
}

\begin{abstract}
This research was conducted in the Geopark Rinjani Lombok Area by looking at the extent to which Regional Regulation No.3 of 2010 was implemented, how the conflict was and its solutions and how a conflict resolution model was found and recommended to be implemented. This research uses descriptive, exploratory and participatory methods with qualitative and quantitative approaches. Data collected by interviewing informants and respondents as well as observing and documenting. The data analyzed by: Overlay map analysis, descriptive analysis, and scoring analysis.

The result of this study are: 1) It is known that the implementation level of spatial policy is at a fairly good level based on an assessment of the four aspects mentioned by George Edward III namely communication, bureaucratic structure, disposition, and resources. 2) Several types of conflicts were found, namely conflicts over spatial use (spacial conflicts) and conflicts of authority. 3) Conflict resolution models carried out by the implementor in implementing Regional Regulation on Spatial Planning, namely legalicy model, persuasive/negotiation model, demolition model, socio-cultural approach model, coordination and synchronization model. 4) Researcher formulate an integrativeparticipatory solution model to resolve conflicts in spatial policy implementation in the Geopark Rinjani Lombok Area. This study also analyzed the implications of the results of the research on the conflict theory proposed by Johan Galtung
\end{abstract}

Keywords : Geopark Rinjani Lombok, Conflict \& Implementation Level Of Spatial Policy

\section{PENDAHUALUAN}

Sejak tahun 2015 beberapa kawasan andalan di Provinsi Nusa Tenggara Barat telah digabung dalam Pembangunan Geopark Rinjani Lombok yaitu kawasan-kawasan yang berada di Gunung Rinjani Lombok (Tim Geopark Rinjani, 2014). Pembangunan Pariwisata di Nusa Tenggara Barat merupakan upaya pemerintah untuk meningkatkan pendapatan daerah, membuka lapangan kerja serta untuk memanfaatkan sumber daya yang dimiliki. Hal ini mengingat pada posisi pariwisata dalam pembangunan Nusa Tenggara Barat (NTB) memegang peran sangat penting. Dapat dilihat bahwa, kontribusi sektor pariwisata dalam Produk Domestik Regional Bruto (PDRB) pada tahun 2012 berkontribusi sebesar 18\% terhadap PDRB NTB (BPS, 2012). Selain daripada itu, menurut laporan tahunan Dinas Pariwisata NTB http://ejurnal.binawakya.or.id/index.php/MBI
(2015), pariwisata berkontribusi juga terhadap perluasan lapangan kerja, perkembangan objek wisata, pembangunan fasilitas-fasilitas atau sarana pariwisata, meningkatkan pendapatan masyarakat, serta meningkatkan kesejahteraan hidup masyarakat.

Tidak hanya menimbulkan dampak positif, disisi lain pembangunan pariwisata juga memunculkan permasalahan-permasalahan, diantaranya adalah : kehancuran sumber daya alam sebagai dampak pembangunan di NTB cukup memprihatinkan. Fisher, et al (1999) dan IDS (2006), mensinyalir laju kerusakan sumber daya alam di NTB cukup tinggi sebagai akibat dari : ledakan penduduk, perambahan hutan karena perladangan liar, pencurian kayu karena illegal logging, kebakaran, konflik masyarakat, penyerobotan hutan, aktifitas ekonomi tambang dan pariwisata, kerusakan sumber daya air,

Vol.13 No.12 Juli 2019

\section{Open Journal Systems}


perubahan iklim, dan bencana alam. Asikin (2014) menemukan konflik yang terjadi pada pemanfaatan dan kepemilikan tanah di Kawasan Pariwisata Gili Trawangan. Konflik yang paling krusial adalah perebutan penguasaan tanah antara PT. Gili Trawangan Indah dengan masyarakat lokal. Hal lainnya dikemukakan oleh Narotama (2013) yang menemukan konflik spatial antara masyarakat lokal dengan pengusaha-pengusaha pariwisata, antara pengusaha pariwisata dengan pemerintah, antara pemerintah dengan penduduk lokal, dan konflik antar penduduk yang memiliki kepentingan yang berbeda. Selain itu, Muktasam (2011) menemukan juga berbagai konflik yang terjadi pada kawasan pariwisata yaitu ditemukannya konflik pemanfaatan pesisir sebagai lahan parkir perahu nelayan dengan pengusaha hotel yang mendirikan bangunan melewati sempadan pantai. Permasalahan lainnya juga dapat dilihat dari adanya tumpang-tindih pemanfaatan ruang/penggunaan lahan, tumpangtindih kewenangan antara pihak-pihak yang berkepentingan (stakeholder) serta adanya ancaman terhadap kesinambungan pembangunan di wilayah konservasi perairan, karena adanya pencemaran perairan laut akibat limbah domestik dan tumpahan bahan bakar dari kapal dan perahu nelayan.

Dalam pembangunan pariwisata NTB, berbagai kebijakan pemerintahan telah dikeluarkan. Dari sekian banyak kebijakan, maka kebijakan perda 3 tahun 2010 tentang Rencana Tata Ruang Wilayah Provinsi NTB dikeluarkan sebagai arahan bagi memanfaatkan ruang wilayah untuk berbagai kepentingan seperti : Ruang Budidaya, Ruang Pembangunan Fasilitas, Ruang Terbuka dan lain-lain. Impelemntasi dari perda ini diharapkan akan mampu menyelesaikan dan memberikan arahan terhadap seluruh masalah yang berkaitan dengan pemanfaatan ruang. Sebagai kebijakan yang diimplementasikan maka perda 3 Tahun 2010 ini akan bisa diukur sejauhmana tingkat implementasinya oleh pelaksanaan kebijakan. Selain daripada itu impelemtasi kebijakan ini memungkinkan memiliki hambatan yang bisa jadi merupakan konflik-konflik dalam penataan

Vol.13 No.12 Juli 2019 ruang. Berdasarkan Laporan Fasilitasi dan Koordinasi Keterpaduan Program Pengembangan Infrastruktur Kawasan Strategis Nasionla (KSN) Gunung Rinjani, Dinas Pekerjaan Umum Provinsi NTB (2016) menemukan beberapa permasalahan dalam penataan Ruang wilayah di Provinsi NTB antara lain : 1) Keterbatasan sumber daya; 2) Masalah kelembagaan yang tumpang tindih; 3) Lemahnya fungsi pengawasan; 4) Masalah konflik atau pelanggaran pemanfaatan ruang; 5) Belum adanya Rencana Detail Tata Ruang Wilayah.

Menurut Hamdi (2013) Kebijakan publik partisipatif adalah suatu kebijakan yang substansi dan prosesnya melibatkan peranserta masyarakat sebagai stakeholder secara berkesinambungan dan proporsional. Esensi dari kebijakan publik partisipatif adalah kesepakatan tentang pola tindakan yang akan diwujudkan sebagai pemanfaatan yang sebesar-besarnya bagi masyarakat. Partisipatif dalam pemahaman penelitian ini merupakan keikutsertaan masyarakat dalam berbagai tahap pembangunan. Menurut Ndraha (1994), bahwa keterlibatan masyarakat dalam pembangunan bisa secara profesional dalam seluruh tahapan pembangunan tetapi bisa juga secara parsial pada satu atau beberapa tahapan saja. Adapun tahap-tahap yang dimaksudkan adalah tahap perencanaan, tahap pelaksanaan, tahap pemanfaatan, tahap pemeliharaan, dan tahap monitoring dan evaluasi.

Bertolak dari uraian dalam Latar Belakang dapat diidentifikasikan beberapa masalah yang dihadapi oleh pemerintah provinsi Nusa Tenggara Barat yaitu: 1) Pemerintah daerah provensi NTB memiliki masalah dalam implementasi Perda Tata Ruang khususnya dalam pengaturan dan pemanfaatan ruang pariwisata berkelanjutan. Permasalahan ini muncul akibat adanya penyimpanganpenyimpangan terhadap Perda Tata Ruang. 2) Pada tahap implementasi Kebijakan Tata Ruang Pemerintah Provinsi NTB masih ditemukan adanya konflik-konflik kepentingan oleh stakeholder pariwisata dalam memanfaatkan ruang yang ada. 3) Adanya penolakan dari sebagian masyarakat terhadap Perda Tata Ruang http://ejurnal.binawakya.or.id/index.php/MBI 
sehingga ada sebagian masyarakat memanfaatkan ruang-ruang tertentu yang bertentangan dengan arahan Perda Tata Ruang. 4) Pemerintah NTB masih mengalami persoalan rusaknya sumberdaya pariwisata atau lingkungan pariwisata seperti kerusakan terumbu karang, kerusakan hutan mangrove, meluasnya krisis lingkungan, serta adanya konflik-konflik yang belum terselesaikan. 5) Peran yang belum optimal dari kelembagaan yang bertanggunga jawab terhadap implementasi Perda Tata Ruang sehingga masih banyak persoalan yang belum terselesaikan. 6) Semenjak dimulainya Pembangunan Pariwisata Berkelanjutan Geopark Rinjani, pemerintah belum merumuskan konsep pembangunan yang jelas tentang pemanfaatan lahan pariwisata, yang bebas konflik menuju keselarasan dan kelestarian sumber daya pariwisata. 7) Pemerintah Provinsi NTB belum mengadakan kajian secara konferhensif terhadap implementasi kebijakan Perda Rencana Tata Ruang Wilayah. 8) Belum adanya model kebijakan dalam penyelesaian konflik secara partisipatif dan komprehensif dalam implementasi Perda Rencana Tata Ruang Wilayah

\section{METODE PENELITIAN}

Penelitian ini menggunakan pendekatan metode gabungan atau kombinasi antara penelitian deskriptif - partisipatif - eksploratif. Metode deskriptif merupakan metode yang mengkaji dan memecahkan persoalan serta memberikan interpretasi dari fakta yang ada saat ini (Nazir, 1998). metode partisipatif merupakan metode penelitian yang memberikan kesempatan penuh pada responden ditentukan sebanyak 30 orang dalam memberikan masukan dalam penyusunan model. Penelitian eksploratif yaitu metode penelitian yang mengkaji dan mengungkapkan sesuatu dari lapangan sebagai suatu temuan yang dapat digunakan untuk menyusun model dan menarik kesimpulan ( Messerschmidt, 1995).

Data dianalisis dengan menggunakan analisis deskriptif yang terdiri dari: 1) analisis tabulasi sederhana untuk mendeskripsikan http://ejurnal.binawakya.or.id/index.php/MBI temuan konflik di lapangan menurut pendekatan pendekatan $5 \mathrm{~W}+1 \mathrm{H}$-- (What, When, Where, Why, Who) dan How, 2) analisis tabulasi silang untuk melihat kesesuaian antara pola penyelesaian yang dilakukan Galtung dengan pola penyelesaian konflik oleh implementor. Selain analisis deskriptif, masalah dalam penelitian ini juga dianalisis dengan menggunakan analisis overlay untuk mengetahui konflik pemanfataan ruang (spasial) dengan menyusun dua peta, yaitu peta tataruang menururt ketentuan sesuai perda dan peta pemanfaatan rung dalam kenyataan (faktual), analisis konten untuk mempelajari konten (isi) antar kebijakan tataruang disandingkan dengan kebijakan-kebijakan lain, serta analisis kewenangan kelembagaan untuk melihat adatidaknya benturan kewenangan antar lemabaga pemerintah baik pada tingkatan administratif maupun tingkatan sektoral.

\section{HASIL DAN PEMBAHASAN}

\section{1) Implementasi Kebijakan Tata Ruang di Geopark Rinjani}

Berbagai hal dalam proses implementasi kebijakan dapat menentukan tingkat keberhasilan suatu kebijaksanaan. . Fase-fase implementasi merupakan faktor penentu dari setiap public policy (Kebijakan Publik), karena setiap kebijakan publik akan menunjukan hasil ketika sebuah kebijakan telah di implementasikan. Jadi public policy tidak hanya sekedar rumusan kebijakan tanpa penerapan guna mewujudkan rencana rumusan dimaksud. Suatu kebijakan publik yang baik harus mampu merumuskan hubungan antara berbagai komponen kebijakan, sehingga antara masukan (Input), proses, hasil (result), dampak (Impact), serta kemanfaatan dapat dirasakan secara nyata pada masyarakat khususnya yang menjadi targetnya. Untuk menganalisis implementasi kebijakan tata ruang wilayah pada Kawasan Geopark Rinjani menggunakan model George Edward III (1980) dengan melihat unsur-unsur : komunikasi, sumber daya, disposisi dan struktur birokrasi dalam penerapan kebijakan Tata ruang wilayah di Kawasan Geopark Rinjani.

Vol.13 No.12 Juli 2019

\section{Open Journal Systems}


Berdasarkan hasil penelitian diketahui bahwa implementasi kebijakan tata ruang wilayah di Kawasan Geipark Rinjani didasarkan pada Peraturan Daerah NTB No.3 Tahun 2010 dimana untuk pengimplementasian PERDA ini maka kewenangan pelaksanaannya Gubernur NTB selanjutnya akan membentuk lembaga bersama BKPRD yang kemudian menyerahkan pelaksanaannya sepenuhnya kepada Bupati/Walikota sesuai dengan wewenang yang diberikan. Tujuan di implementasikannya PERDA Tata Ruang wilayah di NTB adalah untuk menjamin bahwa pemanfaatan ruang sesuai dengan ketentuan.

Setelah dilakukan penelitian didapatkan hasil bahwa tingkat implementasi kebijakan Tata ruang wilayah menurut Asisten II Bidang Ekonomi dan pembangunan Chaerul Machsul yang juga pernah menjabat sebagai Kepala BAPPEDA NTB, tingkat implementasi kebijakan Tata ruang wilayah di Geopark Rinjani berada pada tingkat implementasi cukup baik. Hal ini dapat dilihat pada aspek-aspek berikut ini:

\section{a. Aspek komunikasi}

Komunikasi dalam implementasi kebijakan tata ruang wilayah di Kawasan Geopark Rinjani berada pada tingkatan yang cukup baik. Cukup baiknya komunikasi antara berbagai instansi terkait juga antara stake holder dengan instansi terkait berjalan dengan cukup baik karena melihat frekuensi komunikasi, arah komunikasi, bentuk komunikasi, kejelasan dan efektifitas komunikasi di nilai oleh informan cukup baik. Hal ini juga didukung dengan dibentuknya Badan Koordinasi Penataan Ruang Daerah (BKPRD) sebagai wahana tempat berkomunikasinya antar berbagai lembaga yang terkait dalam implementasi kebijakan tata ruang di daerah masing-masing. Jika komunikasi telah dilakukan dengan cukup baik, maka distorsi implementasi kebijakan tidak akan terjadi.

\section{b. Aspek Sumberdaya}

Sumberdaya yang dimiliki oleh Implementor kebijakan tata ruang di Kawasan Geopark Rinjani yang mencakup sumberdaya manusia, sumberdaya teknologi, sumberdaya finansial dinilai cukup. walaupun kebiijakan yang sudah di komunikasikan cukup baik secara jelas, konsisten dan terarah, bila implementator kebijakan tidak memiliki sumberdaya yang di alokasikan pada sebuah kebijakan, maka implementasi kebijakan tidak akan berhasil.

\section{c. Aspek Disposisi (Sikap)}

Disposisi dari implementator kebijakan Tata ruang wilayah di Geopark Rinjani dipandang cukup baik. implementator kebijakan di NTB cukup memadai bila dilihat dari komitmen, kesungguhan, sifat demokrasi dan tanggung jawabnya dalam melaksanakan tugas yang di lakukannya. Disposisi berupa arahan atasan terhadap bawahan pada jajaran pelaksanaan tugas sebagai implementor kebijakan public dilakukan cukup intensif melalui pertemuan tehnis dan melalui forumforum pembinaan pegawai yang rutin maupun insidential.

\section{d. Aspek Struktur Birokrasi}

The right man on the right place adalah falsafah yang di kedepankan dalam alokasi sumberdaya manusia pada birokrasi yang ada di NTB. struktur birokrasi yang bertugas dalam birokrasi, pelaksanaan kebijakan Tata ruang wilayah adalah cukup memadai. Keberadaan kelembagaan birokrasi dengan penyegaran dan mutasi pegawai serta keberadaan pengawas pegawai negeri sipil (PPNS) yang ditempatkan dalam pengawasan pelaksanaan tata ruang juga dipandang cukup. Masalah yang muncul dari implementasi kebijakan dari aspek struktur birokrasi adalah terkait dengan sumber daya finansial yang dinilai kurang untuk melaksanakan berbagai program.

Berdasarkan analisis skoring yang dibuat menggunakan skala likert dengan 30 orang responden, sebagian besar menyatakan bahwa implementasi kebijakan perda tata ruang berada dalam kategori baik, hanya 4 orang (14\%) yang menyatakan implementasi kebijakan berada dalam kategori kurang baik. Pada aspek sumberdaya sebagian besar responden menilai bahwa sumber daya dalam implementasi kebijakan dinilai masih kurang mengingat banyaknya program yang harus dilaksanakan oleh implentor. Selain itu, kurang tersedianya http://ejurnal.binawakya.or.id/index.php/MBI 
sumber daya manusia yang memiliki kapasitas dan keahlian yang memadai juga menjadi masalah dalam implementasi kebijakan tata ruang mengingay adanya sistem mutasi PNS yang bekerja pada instansi yang mengimplemntasikan kebijakan sering berubah dan penempatan tidak sesuai dengan bidang keahlian.

2) Analisis Implementasi Kebijakan Menurut George Edward III

Model Kebijakan George Edward III secara sederhana dilakukan dengan menganalisis faktor - faktor yang berpengaruh terhadap implementasi kebijakan publik. Adapun faktor yang dimaksud : communication, resources, dispositions dan bireucratic structure (komunikasi, sumber daya, disposisi, dan struktur birokrasi). Bagan model implementasi George Edward III (1980), dapat digambarkan dalam bagan berikut:

Gambar 1. Model Implementasi Kebijakan Menurut George Edward III

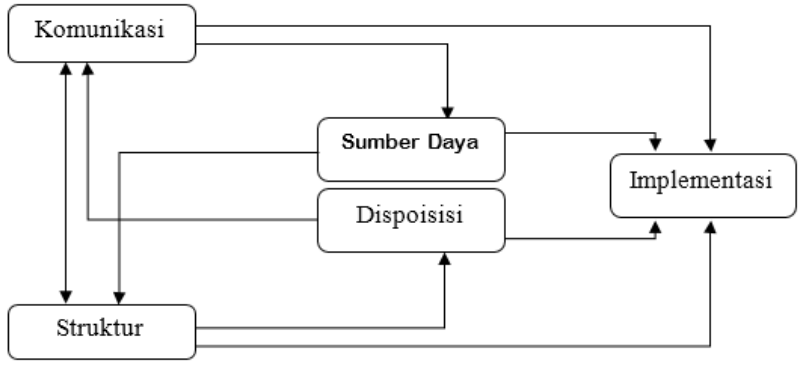

Sumber : Widodo, 2011:107

a. Komunikasi

Dalam berkomunikasi ada beberapa yang dipandang jelas dan ada yang belum jelas. Pada Kawasan Geopark Rinjani Lombok, komunikasi informasi dilakukan melalui forum-forum pertemuan, rapatrapat lintas sektor, serta dapat juga dilakukan dengan menggunakan buku, poster, dan leafleat-leafleat. Bagi khairul Mackhsul komunikasi yang terjadi dalam implementasi kebijakan tata ruang dinilai cukup intensif serta memiliki kejelasan dan konsistensi informasi. Selain itu, dari 30 responden yang diwawancarai menilai bahwa komunikasi yang terjadi antar implementor kebijakan dengan kelompok sasaran sebagian besar ( $72 \%$ ) responden

http://ejurnal.binawakya.or.id/index.php/MBI menyatakan komunikasi berada pada kategori cukup baik.

b. Sumber daya

Aspek sumber daya oleh George Edward III dipandang memiliki peranan yang sangat penting untuk keberhasilan implementasi sebuah kebijakan publik. Di daerah penelitian (NTB) pegawai (staff) yang mengerjakan tugas implementasi kebijakan diamanatkan kepada pegawai-pegawai yang bertugas dibawah subdinas tata ruang wilayah (dinas PUPR NTB). Kapasitas Sumber Daya Manusia sebagai implementor kebijakan tata ruang wilayah berada pada kategori yang cukup. Hanya saja, masalah yang menonjol dari sumber daya manusia yang ada saat ini terkait dengan masalah profesionalitas pegawai yang kurang karena pola rekrutmen pegawai di pemerintahan sering berubah, dan kurangnya sumber daya manusia yang tersedia jika dibandingkan dengan luas wilayah kerjanya. Penilaian responden terhadap keberadaan Sumber Daya Manusia yang melakukan implementasi kebijakan tata ruang sebagian besar (67\%) menyatakan SDM Implementor dianggap cukup.

Anggaran atau budget merupakan faktor yang sangat diperlukan dalam pelaksanaan sebuah kebijakan. Untuk menjamin pelaksanaan kebijakan secara baik dan menyeluruh, diperlukan dukungan dana yang cukup anggaran yang tercurah untuk melaksanakan seluruh program dalam implementasi kebijakan sangatlah kecil (Rp.1-1,2 M/tahun) dimana Sekretaris PUPR NTB menilai dana ini dinilai sangat minim untuk membiayai kegiatankegiatan dalam cakupan wilayah provinsi. Untuk mennyiasati kekurangan anggaran ini, Dinas PUPR harus mencari tambahan - tambahan dari sumber lain berupa kerjasama dengan lembagalembaga funding.

Sumber daya yang tidak kalah pentingnya adalah ketersediaan fasilitas dan sarana dan prasarana sangat dibutuhkan dalam implementasi kebijakan tata ruang. Dalam implementasi kebijakan tata ruang, diperlukan adanya fasilitas - fasilitas seperti gedung, tanah, perkantoran dan peralatannya, kendaraan dan lainnya. sebagian

Vol.13 No.12 Juli 2019 
besarnya sudah tersedia, namun untuk fasilitas fasilitas yang diperlukan secara insidensial, terkadang dipenuhi dengan cara menyewa atau meminjam pada pihak ketiga.

Informasi juga menjadi faktor penting dalam implementasi kebijakan, terutama informasi yang relevan dan cukup terkait bagaimana mengimplementasikan suatu kebijakan. Sementara wewenang berperan penting terutama untuk meyakinkan dan menjamin bahwa kebijakan yang dilaksanakan sesuai dengan yang dikehendaki.

\section{c. Disposisi}

Kecenderungan perilaku atau karakteristik dari pelaksana kebijakan berperan penting untuk mewujudkan implementasi kebijakan yang sesuai dengan tujuan atau sasaran. Sikap dari pelaksana kebijakan akan sangat berpengaruh dalam implementasi kebijakan dimana apabila implementator memiliki sikap yang baik maka dia akan dapat menjalankan kebijakan dengan baik seperti apa yang diinginkan oleh pembuat kebijakan, sebaliknya apabila sikapnya tidak mendukung maka implementasi tidak akan terlaksana dengan baik. Dari hasil penelitian didapatkan bahwa implementor kebijakan didaerah penelitian memiliki sikap yang cukup mendukung kesuksesan/ keberhasilan implementasi kebijakan memiliki sikap posirif. Sikap positif ini ditunjukkan dengan loyalitas dan dedikasi yang cukup baik.

d. Struktur Birokrasi

Birokrasi merupakan kelembagaan yang dibentuk untuk melaksanakan tugas dan fungsi tertentu di dalam menjalankan fungusi pemerintahan. Mekanisme dalam implementasi kebijakan akan biasanya dituangkan dalam standar prosedur kerja yang juga disebut Standar Operational Procedure (SOP) yang digunakan sebagai pedoman kerja dalam melaksanakan tugas implementasi kebijakan tata ruang. Fakta di lapangan menurut Sekda Provinsi NTB, semua SKPD dan Dinas - Dinas yang mengiplementasikan kebijakan tata ruang, ratarata sudah memilki SOP yang jelas. Struktur birokrasi didalam implementasi kebijakan tata ruang sengaja dibentuk oleh Gubernur berupa

Vol.13 No.12 Juli 2019 adanya kelembagaan BKPRD sebagai perpanjangan tugas Gubernur dalam pengendalian dan pelaksanaan kebijakan tata ruang. Dari uraian analisis George Edward terhadap implementasi kebijakan tata ruang di daerah penelitian dinyatakan oleh sebagian besar informan dan responden menilai berada dalam kategori cukup baik.

3) Konflik - Konflik yang Terjadi di Kawasan Geopark Rinjani

Apabila dilihat berbagai jenis konflikkonflik yang terjadi di Geopark Rinjani digolongkan dalam 2 kelompok yiatu konflik spasial dan konflik kewenangan kelembagaan. Berikut akan dijelaskan masing-masing jenis konflik tersebut.

a. Konflik Pemanfaatan ruang (Spatial Conflict)

Konflik pemanfaatan ruang berdasarkan hasil penelitian ini dapat dikategorikan dalam dua bentuk yaitu konflik pada tataran individu dan konflik yang bertataran komunal pada wilayah tertentu. Untuk konflik pemanfaatan lahan pada tataran individu dalam bentuk pelanggaran pemanfaatan ruang disajikan dalam tabel 1 .

http://ejurnal.binawakya.or.id/index.php/MBI

Open Journal Systems 
Tabel 1. Konflik Dalam Pemanfaatan Ruang Untuk Mendirikan Bangunan Oleh Masyarakat Atau Pengusaha Secara Terpisah.

\begin{tabular}{|c|c|c|c|}
\hline No & $\begin{array}{l}\text { Nama } \\
\text { Konflik/Indikasi } \\
\text { Pelanggaran }\end{array}$ & Tempat & Pelaku \\
\hline 1. & $\begin{array}{lrr}\text { Bangunan } & \text { Ruko untuk } \\
\text { budidaya } & \text { burung } \\
\text { wallet } & \text { di } & \text { kota } \\
\text { Mataram. } & & \\
& & \end{array}$ & $\begin{array}{l}\text { Jln. Yos Sudarso dan } \\
\text { Jln. Pejanggik. }\end{array}$ & Pengusaha \\
\hline 2. & $\begin{array}{l}\text { Bangunan Rumah dan } \\
\text { Ruko di sepanjang kali } \\
\text { Ancar. }\end{array}$ & $\begin{array}{l}\text { Kel. Punia, } \\
\text { kel.Mataram Barat } \\
\text { dan kel. Gomong. }\end{array}$ & $\begin{array}{l}\text { Masyarakat } \\
\text { dan } \\
\text { pengusaha. }\end{array}$ \\
\hline 3. & $\begin{array}{lrr}\text { Bangunan } & \text { Villa } & \text { di } \\
\text { sempadan } & & \text { sungai } \\
\text { Meninting. } & & \\
\end{array}$ & $\begin{array}{l}\text { Kel. Bintaro, kota } \\
\text { Mataram. }\end{array}$ & Pengusaha. \\
\hline 4. & $\begin{array}{lr}\text { Bangunan } & \text { Toko, } \\
\text { Restaurant } & \text { dan } \\
\text { pemandian } & \text { mobil } \\
\text { diatas saluran. } & \end{array}$ & $\begin{array}{l}\text { Depan Mataram } \\
\text { Mall, kr. Jangkong, } \\
\text { kota Mataram. }\end{array}$ & $\begin{array}{l}\text { Pengusaha } \\
\text { dan krama } \\
\text { pura }\end{array}$ \\
\hline 5. & $\begin{array}{l}\text { Pembangunan } \\
\text { perumahan Narura } \\
\text { Boutique Residence di } \\
\text { lokasi RTH. } \\
\end{array}$ & $\begin{array}{l}\text { Kel. Sayang-sayang, } \\
\text { kota Mataram. }\end{array}$ & $\begin{array}{l}\text { Pengemban } \\
\text { g/Develope } \\
\mathrm{r}\end{array}$ \\
\hline 6. & $\begin{array}{ll}\text { Bangunan } & \text { Lombok } \\
\text { City Center } & \text { (LCC) di } \\
\text { Narmada. } & \\
\end{array}$ & $\begin{array}{l}\text { Kec. Narmada, kab. } \\
\text { Lombok Barat. }\end{array}$ & Pengusaha. \\
\hline 7. & $\begin{array}{l}\text { Bangunan Villa Hutan } \\
\text { Senggigi. }\end{array}$ & $\begin{array}{ll}\text { Senggigi, } & \text { kab. } \\
\text { Lombok Barat. }\end{array}$ & Pengusaha \\
\hline 8. & $\begin{array}{l}\text { Bangunan hotel di atas } \\
\text { bukit (Hotel Bukit } \\
\text { Senggigi) }\end{array}$ & Senggigi. & Pengusaha. \\
\hline 9. & $\begin{array}{l}\text { Bangunan-bangunan di } \\
\text { atas sempadan pantai } \\
\text { di Gili Trawangan. }\end{array}$ & $\begin{array}{l}\text { Gili Trawangan Kab. } \\
\text { Lombok Utara. }\end{array}$ & Pengusaha. \\
\hline 10. & $\begin{array}{l}\text { Bangunan di } r \text { atas } \\
\text { sempadan dan pantai } \\
\text { Gili Meno. }\end{array}$ & $\begin{array}{l}\text { Gili Meno kab. } \\
\text { Lombok Utara. }\end{array}$ & Pengusaha. \\
\hline 11. & 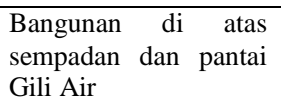 & $\begin{array}{l}\text { Gili Air, } \\
\text { Lombok Utara }\end{array}$ & Pengusaha \\
\hline 12. & $\begin{array}{l}\text { Bangunan Villa Hantu } \\
\text { di atas tebing pantai } \\
\text { Pemenang. }\end{array}$ & $\begin{array}{ll}\text { Pemenang } & \text { kab. } \\
\text { Lombok Utara } & \end{array}$ & Perorangan. \\
\hline 13. & $\begin{array}{l}\text { Bangunan Villa } \\
\text { Bidadari di atas tebing } \\
\text { Pantai Pemenang. }\end{array}$ & $\begin{array}{ll}\text { Pemenang } & \text { kab. } \\
\text { Lombok Utara }\end{array}$ & Perorangan. \\
\hline 14. & $\begin{array}{ll}\text { Pembangunan } & \text { Royal } \\
\text { Villa ditebing } & \text { pantai } \\
\text { Pemenang. } & \\
\end{array}$ & $\begin{array}{l}\text { Pemenang, } \quad \text { kab. } \\
\text { Lombok Utara. }\end{array}$ & Individu \\
\hline 15. & $\begin{array}{l}\text { Pembangunan Toko } \\
\text { dan Restaurant di atas } \\
\text { Bendungan Jenggik. }\end{array}$ & $\begin{array}{l}\text { Jenggik, kab. } \\
\text { Lombok Timur. }\end{array}$ & $\begin{array}{l}\text { Pengusaha } \\
\text { dan } \\
\text { pemerintah } \\
\text { daerah. }\end{array}$ \\
\hline 16. & $\begin{array}{l}\text { Bangunan perumahan } \\
\text { penduduk di sempadan } \\
\text { Pantai Ampenan. }\end{array}$ & $\begin{array}{lr}\text { Kampung } & \text { Banjar, } \\
\text { kampung } & \text { Bangsal } \\
\text { Ampenan, } & \text { kota } \\
\text { Mataram. } & \\
\end{array}$ & $\begin{array}{l}\text { Penduduk } \\
\text { Setempat. }\end{array}$ \\
\hline 17. & $\begin{array}{l}\text { Bangunan perumahan } \\
\text { penduduk di sepadan } \\
\text { pantai. }\end{array}$ & Montong. & $\begin{array}{l}\text { Pendududu } \\
\text { k setempat. }\end{array}$ \\
\hline
\end{tabular}

Sumber: Data Temuan PPNS Tata Ruang (2016)

Dari tabel diatas dapat dilihat beberapa jenis penyimpangan yang dilakukan oleh perorangan/perusahaan yang ditemukan serta harus diresolusi konflik yang terjadi akibat kesalahan pemanfaatan lahan tersebut. Dalam tabel tersebut terdapat 17 jenis pelanggaran yang dalam tiap jenis pelanggaran bisa terjadi banyak individu/perusahaan sebagai pelakunya. Temuan kasus-kasus yang diintentarisin oleh PPNS serta tim BKPRD sebagai wujud Implementasi pengawasan konflik tata ruang telah dilakukan dalam tahun 2017.

Hasil temuan lapangan terhadap konflik penggunaan ruang di Kawasan Geopark Rinjani yang berskala kawasan serta melibatkan masyarakat secara komunal dapat terlihat dalam tabel 2

Tabel 2. Temuan konflik pada penggunaan/pemanfaatan ruang Kawasan Geopark Rinjani

\begin{tabular}{|c|c|c|c|}
\hline No. & Jenis konflik & Tempat & Pelaku \\
\hline & $\begin{array}{lr}\text { Konflik pemanfaatan } \\
\text { ruang } \\
\text { perlindungan } \\
\text { (Konservasi), dengan } \\
\text { fasilitas akomodasi }\end{array}$ & $\begin{array}{lr}\text { Kawasan riga } \\
\text { Gili, } \\
\text { Utara. }\end{array}$ & $\begin{array}{l}\text { KSDA dengan } \\
\text { Pengusaha. }\end{array}$ \\
\hline & $\begin{array}{lr}\text { Konflik } & \text { kawasan } \\
\text { konservasi } & \text { terumbu } \\
\text { karang } & \text { dengan } \\
\text { angkutan laut. } & \end{array}$ & $\begin{array}{l}\text { Kawasan Tiga } \\
\text { Gili dan kawasan } \\
\text { Senggigi. }\end{array}$ & $\begin{array}{l}\text { Departemen } \\
\text { Perhubungan } \\
\text { dengan } \\
\text { Wisatawan. }\end{array}$ \\
\hline & $\begin{array}{l}\text { Konflik pemanfaatan } \\
\text { kawasan hutan dengan } \\
\text { budidaya pertanian. }\end{array}$ & $\begin{array}{l}\text { Senaru, Sesaot, } \\
\text { Bebidas, } \\
\text { Sembalun,Torean }\end{array}$ & $\begin{array}{l}\text { Departemen } \\
\text { Kehutanan } \\
\text { Dengan } \\
\text { Perambah }\end{array}$ \\
\hline & $\begin{array}{l}\text { Konflik penggunaan } \\
\text { lahan konservasi laut } \\
\text { dengan budidaya } \\
\text { rumput laut dan } \\
\text { perikanan tangkap. }\end{array}$ & $\begin{array}{ll}\text { Kawasan } & \text { Tiga } \\
\text { Gili, KLU } & \end{array}$ & $\begin{array}{l}\text { KSDA dengan } \\
\text { Nelayan }\end{array}$ \\
\hline & $\begin{array}{lr}\text { Konflik penggunaan } \\
\text { kawasan konservasi } \\
\text { dengan pelabuhan. }\end{array}$ & $\begin{array}{l}\text { Kawasan Tiga } \\
\text { Gili, dan kawasan } \\
\text { Senggigi. }\end{array}$ & $\begin{array}{ll}\text { KSDA } & \text { vs } \\
\text { Nelayan. } & \end{array}$ \\
\hline & $\begin{array}{lr}\text { Konflik lahan parkir } \\
\text { perahu } & \text { nelayan, } \\
\text { angkutan } & \text { wisata, } \\
\text { pemilik Akomodasi. }\end{array}$ & $\begin{array}{ll}\text { Pantai } & \text { Tiga Gili } \\
\text { dan } & \text { Pantai } \\
\text { Senggigi. } & \end{array}$ & $\begin{array}{l}\text { Pengusaha, } \\
\text { Nelayan dan } \\
\text { Angkutan } \\
\text { Wisata. }\end{array}$ \\
\hline & $\begin{array}{lr}\text { Konflik } & \text { kepemilikan } \\
\text { tanah } & \text { antara } \\
\text { masyarakat } & \text { Gili } \\
\text { Trawangan dengan PT } \\
\text { Gili Trawangan indah. }\end{array}$ & $\begin{array}{l}\text { Gili Terawangan, } \\
\text { KLU. }\end{array}$ & $\begin{array}{l}\text { Masyarakat } \\
\text { dengan } \\
\text { Pengusaha. }\end{array}$ \\
\hline & $\begin{array}{lr}\text { Konflik } & \text { konservasi } \\
\text { dengan angkutan } \\
\text { wisata Bahari. }\end{array}$ & $\begin{array}{lr}\text { Kawasan } & \text { Tiga } \\
\text { Gili, } & \text { KLU, } \\
\text { Kawasan } & \\
\text { Senggigi. } & \end{array}$ & $\begin{array}{l}\text { KSDA dengan } \\
\text { Pengusaha } \\
\text { Angkutan. }\end{array}$ \\
\hline
\end{tabular}

Sumber : Data primer (diolah)

Berdasarkan tabel di atas dapat dilihat bahwa konflik pemanfaatan ruang untuk konservasi dengan fasilitas akomodasi terdapat pada wilayah pesisir dan laut dan wilayah hutan. Kasus konflik pemnfaatan ruang ini terjadi di Gili

\section{Open Journal Systems}


Indah disepanjang pesisir yang tadinya di tetapkan sebagai kawasan hutan mangrove telah di fungsikan dengan mendirikan bangunan, hotel, café dan restaurant. Lahan konservasi yang seharusnya digunakan untuk melindungi daerah pantai dan hutan, tetapi dijadikan fasilitas akomodasi yang menimbulkan terjadinya ketidak seimbangan pemanfaatan lahan dengan beban bangunan yang semakin bertambah (carrying capacity).

Konflik lain yang terjadi di kawasan pantai adalah konflik pemanfaatan lahan konservasi terumbu karang dengan angkutan laut. Aktifitas angkutan laut dengan masuknya kapal-kapal besar yang membawa wisatawan, penambatan jangkar perahu nelayan penangkap ikan secara sembarangan serta aktifitas Olahraga Bahari (Boattrosin, Diving dan Snorkling) telah menjadi ancaman besar terhadap kawasan konservasi terumbu karang. Konflik antara lahan konservasi laut dengan budidaya rumput laut dan perikanan tangkap juga terjadi. Pemanfaatan lahan konservasi untuk budidaya rumput laut serta penangkapan ikan terjadi pada laut dangkal disepanjang KLU dan beberapa tempat dikawasan Senggigi dan Pantai Ampenan.

Konflik lahan konservasi dengan pelabuhan. Faktanya pembangunan pelabuhan pada spot-spot tertentu banyak ditemukan dibangun oleh pribadi atau perusahaan besar. Konflik yang terjadi antara lahan konservasi dengan pelabuhan terjadi di Kabupaten Lombok Utara (KLU, Gili Indah, Amor-amor dan Teluk Nare). Pelabuhan kapal secara illegal di Amoramor adalah pelabuhan laut yang dibuat untuk angkutan batu apung oleh perusahaan tertentu. Masuknya kapal-kapal bermesin jet yang mengangkut wisatawan dari Bali kekawasan Gili Indah dan Senggigi menyebabkan adanya pembangunan pelabuhan oleh swasta pada lahan konservasi. Jika keadaan ini dibiarkan banyak pesisir yang tadinya berfungsi sebagai kawasan konservasi berubah fungsi sebagai pelabuhan. Konflik ini akan berakibat pada ketidak nyamanan wisatawan dengan masyarakat serta aktifis lingkungan.
Pembangunan fasilitas hotel serta fasilitas pendukungnya disempadan pantai (ROI), yang menurut ketentuan perundang-undangan hanya boleh dilakukan 60 meter dari garis pantai (ROI), tapi faktanya banyak pengusaha yang melanggar aturan didalam pembangunan fasilitas akomodasi sehingga kepentingan masyarakat terabaikan. Bagi nelayan-nelayan ikan tangkap menjadi kesulitan dalam memarkir perahu nelayannya sehingga terjadi konflik antara Pengusaha Akomodasi dengan Nelayan, kasus seperti ini ditemukan disepanjang Pantai Senggigi dan Pantai-pantai di Gili Trawangan, Gili Meno dan Gili Air.

Konflik tata ruang wilayah juga terjadi di kawasan hutan lindung di geopark rinjani. Konflik tersebut antara lain adalah Perambahan hutan untuk kepentingan perladangan liar, penanaman tanaman pertanian khususnya pangan dan tanaman semusim lainnya terjadi pada wilayah hutan Senaru, Santong, Sesaot, Persil, Tutul, Pusuk, Batulayar, dan lainnya yang berbatasan dengan pemukiman masyarakat terutama di kantong pemukiman dalam hutan (Enclave) untuk budidaya padigogo (ngerawu). Menyadari peraktik ini pemerintah telah berupaya untuk membendung prilaku petani perambah hutan dengan pelaksanaan Pola Hutan Kemasyarakatan (HKm). Pada beberapa wilayah hutan dengan fasilitasi pembinaan pemanfaatan hutan secara benar

b. Konflik Kewenangan Lembaga Pemerintah (Institutional Conflict)

Dalam penelitian ini dianalisis kewenangan kelembagaan dari beberapa sektor yang terkait dengan implementasi kebijakan tata ruang di Kawasan Pariwisata Berkelanjutan Geopark Rinjani. Analisis ini dimulai dengan penyajian tabel tentang fungsi kewenangan kelembagaan berbagai sektor yang dapat dilihat pada tabel analisis matrik berikut ini :

http://ejurnal.binawakya.or.id/index.php/MBI

Open Journal Systems 
Tabel 3. Matrik Fungsi Dan Wewenang Dari Masing-Masing Lembaga/Instansi Yang Terlibat Dalam Pengelolaan Tata Ruang Di Kawasan Geopark Rinjani

\begin{tabular}{|c|c|c|c|c|c|}
\hline \multirow{2}{*}{$\begin{array}{l}\text { Kegiatan Sektor/ } \\
\text { Urusan }\end{array}$} & \multicolumn{5}{|c|}{ Fungsi manajemen } \\
\hline & Perizinan & Perencanaan & Implementas & $\begin{array}{l}\text { Monitoring/ } \\
\text { Evaluasi }\end{array}$ & $\begin{array}{l}\text { Pengewasan/ } \\
\text { penegendalian }\end{array}$ \\
\hline Penataan Ruang & $\begin{array}{l}\text { - DPMPTSP } \\
\text { DPUPR }\end{array}$ & $\begin{array}{l}\text { - DPUPR } \\
\text { - BAPPEDA }\end{array}$ & DPUPR & $\begin{array}{l}\text { DPUPR } \\
\text { DKP }\end{array}$ & $\begin{array}{l}: \text { DPUPR } \\
\text { DKP } \\
\text { TKPRD }\end{array}$ \\
\hline $\begin{array}{l}\text { Lingkungan Hidup } \\
\text { dan Konservasi }\end{array}$ & $\begin{array}{l}\text { - DPMPTSP, } \\
\text { - Dians LHK, } \\
\text { - BKKPN }\end{array}$ & $\begin{array}{l}\text { - Dinas LHK } \\
\text { - BKKPN } \\
\text { - BAPPEDA }\end{array}$ & 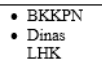 & $\begin{array}{l}\text { - BKKPN } \\
\text { - Dinas LHK } \\
\text { - BAPPEDA }\end{array}$ & $\begin{array}{l}\text { - Dinas LHK } \\
\text { - BKKPN } \\
\text { - TNI -AL. }\end{array}$ \\
\hline $\begin{array}{l}\text { Kelautan } \\
\text { Perikanan }\end{array}$ & $\begin{array}{l}\text { - DPMPTSP } \\
\text { - Dinas KP } \\
\text { - BKKPN }\end{array}$ & $\begin{array}{l}\text { - Dinas KP } \\
\text { - BKKPN } \\
\text { - BAPPEDA }\end{array}$ & $\begin{array}{l}\text { - Dinas KP } \\
\text { - BKKPN } \\
\text { - Swasta }\end{array}$ & $\begin{array}{l}\text { - Dinas KP } \\
\text { - BKKPN } \\
\text { - BAPPEDA, } \\
\text { - Dinas PUPR }\end{array}$ & $\begin{array}{l}\text { - Dinas KP } \\
\text { - TNI - AL, } \\
\text { - Dinas LHK }\end{array}$ \\
\hline Pariwisata & $\begin{array}{l}\text { - DPMPTSP } \\
\text { (rekom Dinas } \\
\text { Pariwisata } \\
\text { dan Dinas } \\
\text { PUPR) }\end{array}$ & $\begin{array}{l}\text { - KemenPar } \\
\text { - Dinas } \\
\text { Pariwisata } \\
\text { - BAPPEDA }\end{array}$ & $\begin{array}{l}\text { - Dinas } \\
\text { Pariwisata } \\
\text { - BKKPN }\end{array}$ & $\begin{array}{l}\text { - KemenPar } \\
\text { Dinas } \\
\text { Pariwisata } \\
\text { - BKKPN } \\
\text { - BAPPEDA } \\
\text { - Dinas LHK }\end{array}$ & $\begin{array}{l}\text { - KemenPar } \\
\text { Dinas } \\
\text { Pariwisata } \\
\text { - BKKPN } \\
\text { - Dinas LHK } \\
\text { TNI-AL }\end{array}$ \\
\hline Perhubungan & $\begin{array}{l}\text { DPMPTSP } \\
\text { (rekom } \\
\text { Dishub) } \\
\text { - BKKPN }\end{array}$ & $\begin{array}{l}\text { - BAPPEDA } \\
\text { - Dishub }\end{array}$ & $\begin{array}{l}\text { - Dishub } \\
\text { - KUPP } \\
\text { Pemenang }\end{array}$ & $\begin{array}{l}\text { - Dishub } \\
\text { - BAPPEDA, } \\
\text { - DKP } \\
\text { - DLHK }\end{array}$ & $\begin{array}{l}\text { - Dishub } \\
\text { - BKKPN } \\
\text { - TNI -AL, } \\
\text { - Dinas LHK }\end{array}$ \\
\hline $\begin{array}{l}\text { Penelitian dan } \\
\text { Pengembangan }\end{array}$ & - BAPPEDA & - BAPPEDA & - BAPPED & - BAPPEDA, & - BAPPEDA \\
\hline Pertanahan & $\begin{array}{l}\text { - DPMPTSP } \\
\text { Kanwil BPN }\end{array}$ & 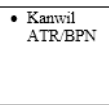 & $\begin{array}{l}\text { Kanwil } \\
\text { ATR/BP } \\
\mathrm{N}\end{array}$ & 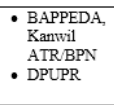 & $\begin{array}{l}\text { - Kanwil } \\
\text { ATR/BPN } \\
\text { - BKKPN } \\
\text { - TNI -AL, } \\
\text { - DPUPR }\end{array}$ \\
\hline
\end{tabular}

Berdasarkan tabel di atas, ditemukan tumpang tindih kewenangan antara apa yang diatur oleh kelembagaan pemerintah dalam jenjang yang berbeda. Sebelum tahun 2014 pengelolaan hutan masih berada di kewenangan Pemerintah Daerah Tingkat II, namun sejak diberlakukannya Undang-Undang No.23 Tahun 2014 kewenangan pengelolaan hutan, pesisir dan laut kewenangan untuk pengelolaan kawasan hutan tersebut dialihkan sepenuhnya menjadi kewenangan provinsi yang mengakibatkan banyak terjadinya tumpang tindih kewenangan antara provinsi dan kabupaten/kota.

Kasus lain ditemukan di Hutan Sesaot, Kabupaten Lombok Barat. Kawasan Hutan Sesaot yang mestinya menjadi kewenangan pengelolaan Dinas Kehutanan dan Lingkungan Hidup Provinsi NTB, namun pada kenyataannya Dinas Pariwisata Kabupaten Lombok Barat telah menetapkan Kawasan Hutan tersebut menjadi objek wisata. Solusi yang ditempuh pemerintah atas konflik ini adalah melakukan koordinasi ulang terhadap pemanfaatan Kawasan Hutan Sesaot menjadi objek wisata. Dengan menyadari kewenangan Pemda Tingkat II Kabupaten Lombok Barat yang menurut UU No.23 Tahun 2014 yang tidak lagi memiliki kewenangan terhadap pengelolaan kawasan hutan, maka
Pemerintah Daerah Tingkat II Kabupaten Lombok Barat kemudian memohon ijin kepada Pemda Tingkat I NTB dan membuat pola kerjasama pengelolaan Kawasan Hutan Sesaot sebagai objek wisata. Sistem kerjasama ini memberikan kepastian hukum terhadap pemanfaatan hutan sesaot yang berdampak pada peningkatan pendapatan dari kedua belah pihak sesuai kesepakatan pembagian hasil.

Konflik lain terjadi pada Kawasan Hutan Bebidas yang masuk kedalam kawasan Hutan Sembalun yang ditetapkan sebagai kawasan konservasi oleh pemerintah. Tetapi masyarakat yang menempati wilayah tersebut menggunakan wilayah hutan untuk usaha perkebunan dan pariwisata, sehingga saat ini Kawasan Hutan Bebidas sedang terjadi konflik kepemilikan dan pemanfaatan ruang antara pemerintah dengan masyarakat setempat. Solusi penyelesaian konflik atas masalah ini telah diupayakan dengan beberapa cara diantaranya adalah dengan melalui penyelesaian musyawarah, namun tidak menemukan titik sepakat antara kedua belah pihak.

Konflik kewenangan kelembagaan ini juga terjadi Kawasan Senggigi dan Tiga Gili yang disebabkan oleh ketidakjelasan pembagian wewenang antara pemerintah pusat dan daerah terutama berkaitan dengan kewenangan terhadap fungsi perijinan, perencanaan, pengawasan dan pengendalian. Dalam hal perencanaan terdapat empat lembaga yang berwenang membuat dokumen Rencana Tata Ruang Wilayah dengan hasil yang berbeda. Keempat lembaga tersebut adalah Bappeda Provinsi NTB yang membuat Rencana Tata Ruang Wilayah Provinsi NTB, Dinas PUPR Provinsi NTB yang membuat Rencana Tata Ruang Wilayah KSP Senggigi Tiga Gili, Dinas Kelautan dan Perikanan Provinsi NTB yang membuat Rencana Zonasi Wilayah Pesisir Senggigi dan Tiga Gili serta Bappeda Kabupaten Lombok Barat dan Lombok Utara yang membuat Rencana Tata Ruang Wilayah KSK. Pelaksanaan fungsi pengawasan dan pengendalian juga terjadi konflik kewenangan antar 5 lembaga. Kelima lembaga tersebut adalah Kepolisian, TNI Angkatan Laut, Satuan Polisi

Vol.13 No.12 Juli 2019 
Pamong Praja sebagai penegak Perda dan Kelompok Kerja Tim Koordinasi Penataan Ruang Daerah serta PPNS Tata Ruang.

Fakta di lapangan juga ditemukan adanya konflik perizinan pada kawasan pesisir dan laut. Menurut Undang-Undang No. 27 Tahun 2007 Tentang Pengelolaan Wilayah Pesisir dan PulauPulau Kecil. Kasus di Gili Trawangan, Gili Meno dan Gili Air dimana BKSDA sesuai dengan Keputusan Menteri Kehutanan, menetapkan adanya kapasitas ruang (carrying capacity) di kawasan Gili Trawangan, Gili Meno dan Gili Air dibatasi hingga maksimal 300 kamar pada tiap gili. Namun, kenyataannya pemerintah daerah setempat (Pemda tingkat II KLU) sudah memberikan IMB lebih dari 1500 kamar sehingga terjadi over capacity yang akhirnya menjadi konflik kewenangan yang serius. Terhadap kasus ini belum ada solusi untuk menyelesaikannya sehingga kedepan haruslah dicarikan solusi melalui kordinasi antar lembaga.

\section{4) Analisis Overlay dalam melihat konflik pemanfaatan ruang}

Teknik overlay map dalam menganalisa tumpang tindih pemanfaatan ruang dapat dilakukan. Overlay merupakan proses penyatuan data dari lapisan layer yang berbeda, secara sederhana overlay disebut sebagai operasi visual yang membutuhkan lebih dari satu layer untuk digabungkan secara fisik. Untuk melihat tumpang tindih pemanfaatan ruang sebagai bentuk konflik spasial terhadap kondisi di Nusa Tenggara Barat, tidak dapat dilakukan karena implementor kebijakan tata ruang belum memiliki peta RDTL (Rencana Detail Tata Ruang) serta tidak memiliki tentang realisasi detail penggunaan ruang oleh stakeholder. untuk kawasan Gili Trawangan dan Kawasan Senggigi yang merupakan bagian dari wilayah Geopark Rinjani telah dilakukan analisis overlay dengan melihat dari peta rencana zonasi pengembangan wilayah KSP senggigi dan Tiga Gili dengan Peta Pemanfaatan Zonasi Wilayah KSP Senggigi dan Tiga Gili. Hasil yang didapatkan dari analisis overlay ini adalah ruang yang seharusnya diperuntukkan direncanakan sebagai lahan konservasi difungsikan sebagai pembangunan akomodasi dan fasilitas wisata, lahan yang sesungguhnya diperuntukkan sebagai lahan budidaya rumput laut justru berbenturan dengan kepentingan untuk spot pariwisata. Lahan yang seharusnya digunakan sebagai lahan konservasi justru dimanfaatkan sebagai pelabuhan dan sebagai zona pelayaran angkutan laut.

\section{5) Model Resolusi Konflik Tata Ruang Pembangunan Pariwisata}

a. Modal Legalicy.

Model penyelesaian ini merupakan penyelesaian konflik melalui jalur hokum formal yang mengandalkan penyelelsaian konflik dengan mengajukan setiap pelanggaran/konflik tata ruang dengan melakukan pelaporan dan penindakan dengan mengajukannya sebagai pelanggaran hukum dan penyelesaiannya melalui sidang pengadilan. alur peyelesaian konflik dengan model Legalicy ini dapat digambarkan sebagai berikut:

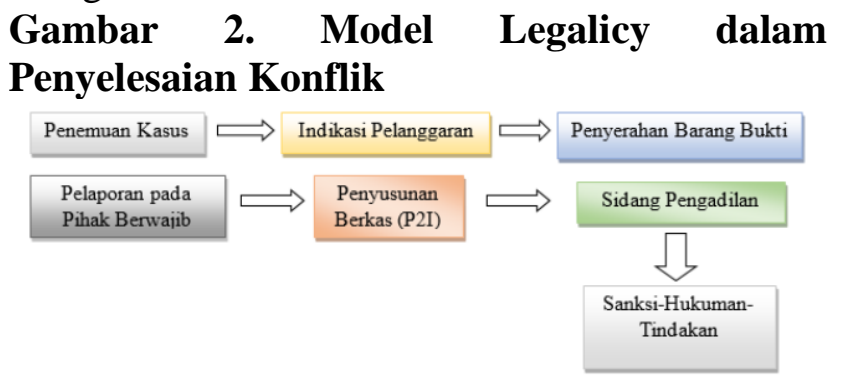

Secara teoritis model penyelesaian konflik melalui model Legalicy ini sejalan dengan teori Johan Galtung (1973) yang juga menyatakan bahwa penyelesaian konflik melalui jalur hukum formal dengan beracara di Pengadilan Negara merupakan cara penyelesaian konflik yang paling formal.

a. Model Persuasif/Mediasi

Menyelesaikan konflik tata ruang juga dapat dilakukan dengan model persuasif atau dengan pendekatan mengetuk kesadaran. Caracara seperti ini banyak dilakukan oleh implementor kebijakan melalui himbauanhimbauan penertiban dan pendekatan-pendekatan informal. Pada Kawasan Geopark Rinjani banyak pengumuman, himbauan dan peringatan yang dilakukan oleh implementator kebijakan untuk menyelesaikan konflik. Beberapa himbauan

http://ejurnal.binawakya.or.id/index.php/MBI 
dengan pemasangan papan perumpatan dan atau teguran pada pelanggaran pemanfaatan Tata ruang dapat ditemukan pada beberapa Sport Pariwisata yang penting pada Kawasan Geopark Rinjani.

b. Model Penertiban dan Pembongkaran

Model penertiban dan pembongkaran dilakukan melalui operasi khusus yang melibatkan berbagai pihak seperti Kepolisian dan Polisi Pramong Praja (Pol PP). Model penyelesaian seperti ini dilakukan setelah melalui tahap-tahap himbauan, negosiasi dan teguranteguran sebelumnya. Model Penyelesaian konflik dengan cara pembongkaran sering terjadi misalnya saja pembongkaran lapak pedagang di sepanjang pantai Gili Trawangan dan pembongkaran bangunan ruko yang tidak memenuhi ketentuan yang terdapat di Kawasan Geopark Rinjani pada tahun 2017.

c. Model Pendekatan Sosial Budaya

Penyelesaian konflik melalui Model Sosiso Kultur dilakukan oleh masyarakat dikawasan pariwisata dengan pola-pola kearifan budaya. Penetapan awig-awig sebagai bentuk regulasi lokal yang disusun masyarakat secara musyawarah berdasarkan kearifan budayanya terbukti mampu mencegah dan atau mengatasi konflik Tata ruang di kawasan pariwisata tertentu. Beberapa awig-awig yang diterapkan adalah Awig-awig Keamanan Segare di Gili Indah (kabupaten Lombok Utara) untuk mengatur perilaku masyarakat dalam mengamankan kawasan laut dari perilaku yang menyimpang dan Awig-Awig Ngaro Ngarat di Desa Bayan dimana awig-awig ini menjalin kesepakatan petani dan peternak dalam menjalankan kegiatan masing-masing tanpa melakukan pelanggaran-pelanggaran yang dapat merugikan kepeningan banyak pihak.

d. Model Koordinasi Kelembagaan antar Pemerintah dan Sinkronisasi Antar Sektor

Konflik antar kelembagaan pemerintah bisa saja terjadi baik antar Pemerintah Pusat, Provinsi, dan Pemerintah Daerah Tingkat II akibat kepentingan yang berbeda atau karena pemahaman terhadap kewenangan masinghttp://ejurnal.binawakya.or.id/index.php/MBI masing masih kurang. Hal ini bisa terjadi karena sering terjadi perubahan nomenklatur serta tupoksi masing-masing. bila terjadi hal seperti ini, maka jalan penyelesaian yang ditempuh biasanya adalah dengan mengadakan koordinasi, konsultasi, dan sinkronisasi.

e. Model Revisi Kebijakan Tata Ruang

Revisi Kebijakan Tata Ruang merupakan suatu model menyelesaikan konflik yang meluas yang dilakukan oleh Pemerintah Daerah. Jika penyimpangan pelanggran tata ruang sampai diatas 30\% maka UUTRN (Undang-undang Tata Ruang Nasional), telah mengamanatkan perlunya Revisi Tata Ruang yang ditetapkan dengan Peraturan Daerah.Terdapat 2 Kabupaten dan Kota yang wilayahnya termasuk dalam Kawasan Geopark Rinjani tahun 2017 ini yang sedang mengajukan Revisi Perda Tata Ruangnya, yaitu Kabupaten Lombok Utara dan Kota Mataram. Tingkat pelanggaran pemanfaatan ruang menurut di Kota Mataram sudah mencapai diatas 30\% dalam lima tahun terakhir, sedangkan pelanggaran pemanfaatan tata ruang di Kabpuaten Lombok Barat saat ini sudah mencapai $27 \%$, sehingga kedua Kabupaten dan Kota tersebut sedang dalam proses pengajuan revisi kebijakan tata ruangnya masing-masing.

Model Resolusi Konflik Kebijakan Tata Ruang Secara Integratif Partisipatif

Adapun Model Resolusi Konflik Integratif ini peneliti rancang sebagai temuan baru yang ditawarkan, sebagaimana tersaji dalam chart berikut ini: 
Gambar 3. Model Resolusi Konflik Implementasi Kebijakan Tata Ruang Wilayah Secara Integratif Partisipatif (Model Johan Bachry, 2019)

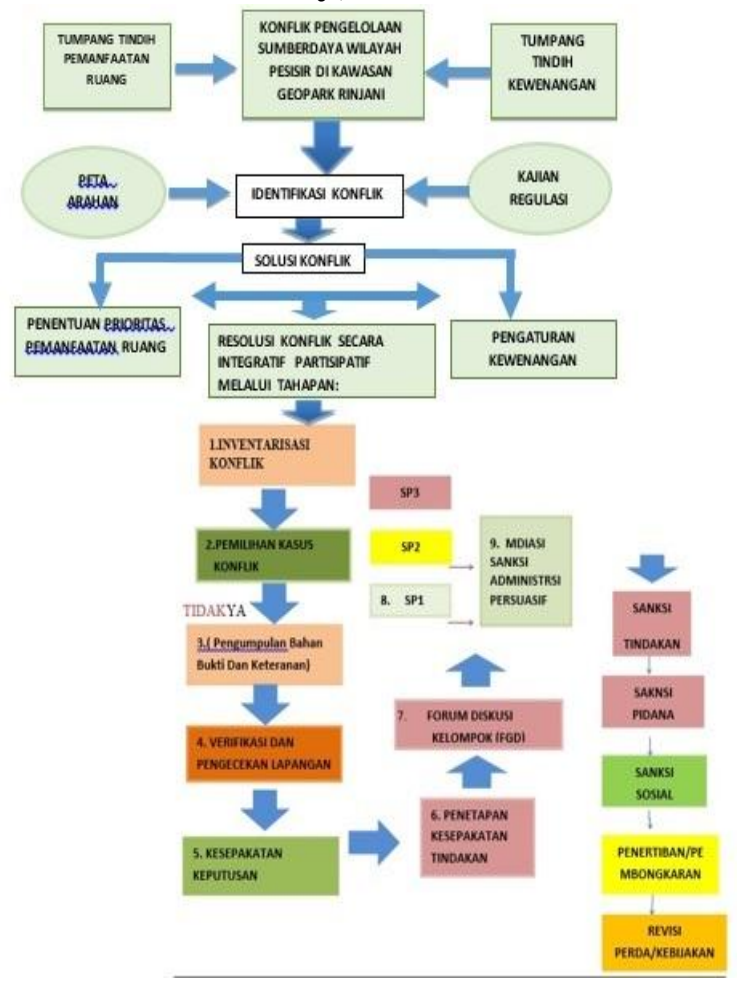

Model yang diajukan peneliti ini merupakan akomodasi dari fenomena dan langkah-langkah yang selama ini telah dirumuskan oleh tim Forum Group Disscussion, model ini bermula dari inventarisasi konflik-konflik yang terjadi diseputar Kawasan Geopark Rinjani.

\section{6) Implikasi Penelitian Terhadap Teori}

Pada prinsipnya pola penyelesaian konflik yang dikemukakan dalam teori Johan Galtung ada empat yaitu model dialog, model negosiasi, model mediasi dan model peace building. Sesuai dengan hasil penelitian yang dilakukan, implementasi dari teori resolusi konflik yang dikemukakan oleh Galtung tersebut juga samasama diterapkan atau digunakan didalam penyelesaian konflik terkait tata ruang di Kawasan Geopark Rinjani saat ini. Implikasi teori resolusi konflik Johan Galtung dapat dilihat dari penyelesaian konflik di Kawasan Geopark Rinjani melalui model persuasif dan model sosial budaya yang dilakukan dengan cara informal melalui dialog, pemberitahuan, pertemuan, serta melibatkan pihak lain untuk menemukan solusi bersama. Sedangkan di sisi lain, model penertiban dan pembongkaran yang dilakukan di kawasan Geopark Rinjani dianggap bertentangan dengan teori resolusi konflik dengan pendekatan peace building yang dikemukakan oleh Galtung. Adanya penertiban dan pembongkaran ini seringkali menimbulkan konflik baru antara pemilik gedung, bangunan atau properti tertentu yang menghalangi terciptanya peace building sebagaimana dinyatakan dalam resolusi konflik oleh Galtung.

Terdapat model penyelesaian konflik baru yang tidak tidak disebutkan dalam teori Galtung tetapi muncul sebagai jalan penyelesaian konflik yang terjadi di daerah penelitian Kawasan Geopark Rinjani yaitu: 1) model koordinasi kelembagaan antar pemerintah dan sinkronisasi antar lembaga yang dilakukan dengan mengadakan koordinasi, konsultasi dan sinkronisasi antar lembaga dan antar sektor dalam pemerintahan, 2) model revisi kebijakan tata ruang dimana revisi tata ruang ditetapkan dengan peraturan daerah jika pelanggaran dalam tata ruang telah mencapai $30 \%$.

Implikasi teori lainnya terkait dengan teori Thomas Kilmann yang menyatakan ada $\mathrm{n}$ lima metode yang digunakan dalam menyelesaikan konflik yaitu metode kompetisi, metode kolaborasi, metode kompomi, metode pembiaran dan metode akomodasi. Dari kelima metode yang dipaparkan oleh Thomas Kilmann tersebut, pada kenyataannya di lapangan, Pemerintah Daerah Provinsi Nusa Tenggara Barat menerapkan dua metode penyelesaian konflik dalam mengatasi adanya konflik tata ruang yang terjadi pada Kawasan Geopark Rinjani yaitu: 1) dengan melakukan tindakan pembiaran dimana bangunan yang menyalahi aturan Disepanjang Jalan Raya Senggigi, serta Pinggiran Kali Ancar dan Kali Jangkok tidak ditindaklanjuti untuk menghindari konflik yang lebih besar. 2) dengan kompromi dimana dalam penyelesaian konflik pemanfaatan ruang untuk parkir perahu dengan pemnfaatan fasilitas pariwisata yang terjadi di Kawasan Senggigi diselesaikan secara kompromi antara pemilik hotel dengan nelayan (pemilik

http://ejurnal.binawakya.or.id/index.php/MBI 
perahu) dilakukan oleh aktor yang berkonflik dibantu oleh pemerintah yang bertindak sebagai mediator.

Teori Dahrendorf (1959) yang berkenaan dengan penyelesaian konflik yang terdiri dari metode konsiliasi, metode mediasi, dan metode arbitrasi, disisi lain tidak diterapkan pada penyelesaian konflik tata ruang di Kawasan Geopark Rinjani terutama penyelesaian menggunakan teknik konsiliasi dan arbitrasi karena konflik yang dimaksud dalam penelitian ini bukan merupakan konflik fisik antar masyarakat, pemerintah, atau pengusaha secara fisik, melainkan konflik terkait dengan pemanfaatan lahan, konflik kewenangan dan konflik regulasi, sehingga tidak ada aktor yang perlu dikonsiliasi.

\section{PENUTUP}

\section{Kesimpulan}

Dalam penelitian ini, setelah memperhatikan hasil dan pembahasan, maka dapat dikemukakan bebrapa kesimpulan sebagai berikut: 1) Tingkat implementasi Kebijakan Tata Ruang Wilayah di Kawasan Geopark Rinjani Lombok berada pada kategori cukup baik berdasarkan aspek - aspek yang di kemukakan oleh George Edward III (1980). 2) Ditemukan berbagai jenis konflik yang terjadi dalam implementasi Kebijakan Tata Ruang di Kawasan Geopark Rinjani yaitu konflik pemanfaatan lahan pada tataran individu, konflik pemanfaatan lahan pada kawasan ruang publik (konflik spasial), dan konflik kewenangan antar kelembagaan. 3) Ditemukan pola penyelesaian konflik implementasi Kebijakan Tata Ruang di Kawsan Geopark Rinjani yaitu model legalicy, model persuasive/negosiasi, model penertiban dan pembongkaran, model pendekataan sosialbudaya, model koordinasi dan sinkronisasi antar sektor, model revisi peraturan daerah mengenai Kebijakan Tata Ruang. 4) Dapat ditemukan model-model penyelesaian konflik Implementasi Tata Ruang secara parsial dalam 4 model yakni: Model Legalicy, model Persuasif, model Penertiban/pembongkaran, model Sosio kultur dan model Revisi Kebijakan. 5) Dapat http://ejurnal.binawakya.or.id/index.php/MBI

\section{Open Journal Systems}

dirumuskannya model Resolusi Konflik secara Integratif Partisipatif yakni model Resolusi Konflik Integratif Partisipatif Johan Bachry, 2018.

\section{DAFTAR PUSTAKA}

[1] Abd. Rahim dan Riah Retno Dwi Hastuti. 2007. Ekonomika Pertanian, Pengantar Teori dan Kasus. Penebar Swadaya.

[2] Agustino, Leo. 2008. Dasar-dasar Kebijakan Publik. Alfaberto.

[3] Al Fatih, Andy. 2010. Implementasi Kebijakan dan Pemberdayaan Masyarakat. Bandung. UNPAD Press.

[4] Aminah, S. 2015. Konflik dan Kontestasi Penataan Ruang Kota Surabaya. MASYARAKAT: Jurnal Sosiologi, halaman 59-79. Sumber: http://www.mercubuana.ac.id

[5] Anderson, James. 1979. Public Policy Making (Second. ed) New York: Holt Renehart and Winston. New York.

[6] Antlov H. 2005. Perlibatan Publik Dalam Pengambilan Keputusan. LP3ES Jakarta

[7] Asikin Zainal, 2014, Konflik Pertanahan dan Solusi di Gili Trawangan, Laporan Penelitian Dana DPP-UNRAM

[8] Budiardjo, Miriam. 2012. Dasar-dasar Ilmu Politik. Jakarta: Gramedia Pustaka Utama

[9] Bachry, Johan. 1997. Transformasi Agro Tourism Dampaknya terhadap Perubahan Kerajaan Keluarga Di Kawasan Pariwisata Gili Indah - Lombok. Tesis S2. IPB Bogor

[10]Blau, P.M. 1964. Exchange and Power in Social Life. New York: Wiley.

[11]Dahrendorf, Ralf. 1959. Class and Class Conflict in Industrial Society, (London:Routledge; First Pub. 1957).

[12]Davis, K. Newstorm, 1977. Human Behavior at Work. Organization Behavior New York.

[13]Dipokusumo, Bambang. 2011. Model Partisipatif Perhutanan Sosial Menuju Pengelolaan Hutan Berkelanjutan (Kasus Pembangunan Hutan Kemasyarkatan pada Kawasan Hutan Lindung di Pulau Lombok). Disertasi. IPB. Bogor

Vol.13 No.12 Juli 2019 
[14]Dye. Thomas R, 2005. UnderstandingPublic Policy. Eleventh Edition, New Jersey: Pearson Prentice Hall.

[15]Edward III ,1980, Implementing Public Policy, Washington DC, Congressional Quartely Press

[16]Fahmi E,. Zakaria RY., Hariadi K. Dan Wahono F.2003. INSIST-Minus Malum. Analisis Proses Perhutanan Multipihak di Indonesia. Laporan Hasil Penelitian Insist dan Mitra. Yogyakarta.

[17]Fisher L., Moeliono I., Wodicka S.1999. The Nusatenggara Uplands, Indonesia: MultipleSite Lessons in Conflict Management. Source: http://www.indrc.ca/1999.

[18]Friedrich, Carl J., 1963. Man and HIS Goverment. New York: McGraw-Hill.

[19] Galtung, Johan. 1973. Theories of Conflict. University of Hawaii

[20] Goodman D.J . dan Rizer G. 2003. Teori Sosiologi Modern. Edisi Keenam. Diterjemahkan oleh Alimandan. Perpustakaan Nasional. Jakarta.

[21] Grindle, Merilee S. (ed). 1980. Policts and Policy Implementations in the Third Word. New Jersey: Prince Town University Press.

[22] Hamdi, Muchlis. 2013. Kebijakan Publik Proses Analisis Dan Partisipasi. Ghalia Indonesia

[23]Homans, G.C. 1961. Social Behavior and Its Elementary Form. New York: Harcourt, Brace and World.

[24] Howell RE,. Olsen ME,. And Olsen D. 1087. Designing Acitizen Invovement Program. Guide Book for Involving. Citizens in the resolution of Environment issues. Western Rural Develpoment Center. Oregon State University. Corvallis Oregon. USA.

[25]IDS. Institute Development Studies 2006. University of Sussex Understanding Policy Processes. Brigton BNI 9RE

[26]Jazuli, Ahmad. 2017. Penegakan Hukum Penataan Ruang Dalam Rangka Mewujudkan Pembangunan Berkelanjutan. Jurnal Rechts Vinding: Media Pembinaan Hukum Nasional Vol. 6 No.2. Sumber: http://www.bphn.go.id

Vol.13 No.12 Juli 2019
[27]Keraf S. 2002. Etika Lingkungan. Jakarta. Buku Kompas.

[28] Klidas Sasker, Ligia Noronha et all. 1998. Tourism And Environment. The Economic Development. Institute Of World Bank

[29] Kartodihardjo. 2006. Politik Lingkungan Dan Kekuasaan Di Indonesia. Equenox Publishing Indonesia

[30] Harold D. Lasswell. 2009. Structure an Function of Communication in Societ dalam Wilbur Schramm (Ed).

[31] Markum. 2006. Kebijaan HKm di NTB: Prakasra yang Terlambat. Pengelolaan Hutan Berbasis Masyarakat. Perjalanan Menuju Kepastian. Rahardjo DY, Haris S. Dan Erna $\mathrm{R}$ (Editor). Jakarta. Dirjen RLPS Departemen Kehutananan Republik Indonesia dan The Ford Foundations.

[32] Marsel Schmidth DA. 1995. Rapid Appraisal For Community Methodology Series. International Institute Of Environment And Development UK London

[33] Muktasam, Bambang D., Bambang HK., Markum., Rosiyadi S., dan Siti H. 2003. Implementasi Argoforesty dan Sistem Usahatani Terpadu Melalui Partisipasi Masyarakat Daerah Pinggiran Hutan dan Lahan Kering Miring. Mataram. Laporan Penelitian P3P Universitas Mataram.

[34] Narotama Nararia, 2013, Konflik Spasial antar Stakeholder Pariwisata di Badung, Laporan Penelitian

[35] Nazir M. 1998. Metode Penelitian. Ghalia Indonesia

[36]Ndraha Taliziduhu, 1994, Partisipasi Masyarakat dalam Pembangunan, Rineka Cipta Jakarta

[37] Nurrochmat D.R. 2005. Strategi Pengelolaan Hutan. Upaya menyelamatkan Hutan Rimba yang Tersisa. Yogyakarta. Putaka Pelajar.

[38] Pemerintah NTB. 2010. Naskah Lengkap PERDA Nomor 3 tentang Rencana Tata Ruang Wilayah Propinsi Nusa Tenggara Barat Tahun 2009-2029.

[39] Pemerintah NTB. 2013. Nusa Tenggara Barat Dalam Angka 2013

http://ejurnal.binawakya.or.id/index.php/MBI 
[40]Raba, Manggaukang, 2012, Menuju Nusa Tujuan Berwisata, Perpustakaan Nasional RI, Arga Puji Press Mtaram Lombok.

[41]Stephen P. Robbins, 1996. Perilaku Organisasi. PT. Bhuana Ilmu Populer, Jakarta

[42] Suprahardjo. 2005. Manajemen Kolaborasi. Memahami Prularisme Membangun Konsensus. Pustaka Latin Bogor

[43] Suradinata, Ermaya. 1996. Manajemen Sumber Daya Manusia. Jakarta.

[44] Thibaut, J.W, \& Kelly, H. H.. 1959. The Psychology of Social Gruop; New York: John Willey \& Sons, Inc.

[45]Tim Geopark Rinjani Lombok. Dokumen Usulan Geopark Nasional dan Geopark Dunia. 2013

[46]Winarno, Budi. 2014. Kebijakan Publik: Teori, Proses dan Studi Kasus. Yogyakarta, Center of Academic Publishing Service (CAPS)

[47]Keputusan Presiden Republik Indonesia Nomor 26 Tahun 2011 tentang Penetapan Cekungan Air Tanah

[48]Keputusan Kementrian Kelautan Dan Perikanan Republik Indonesia Nomer 67/MEN / 2009 Tentang Penetapan Kawasan Konservasi Perairan Nasional Pulau Gili.

[49] Keputusan Kepala Bappeda Propensi Nusa Tenggara Barat Nomor 097 Tahun 2014 Tentang Pembentukan Seketariat Tim Fasilitasi Geopark Rinjani Sebai Geopark Dunia.

[50] Keputusa Gubenur Nusa Tenggara Barat Nomor 556 - 318 Tahun 2014 Tentang Pembentukan Tim Fasilitasi Geopark Rinjani Sebagai Geopark Dunia.

[51]Laporan Pemetaan Masalah Kehutanan NTB, 2006

[52]Badan Pusat Statistik NTB, 2009-2012.

[53] Peraturan Daerah Provinsi NTB Nomor 3 Tahun 2010 tentang RTRW Provinsi NTB

[54]Peraturan Daerah Kabupaten Lombok Timur Nomor 2 Tahun 2012 Tentang RTRW Kabupaten Lombok Timur.

[55]Peraturan Daerah Kota Mataram Nomor 12 Tahun 2011Tentang RTRW Kota Mataram.
[56]Peraturan Daerah Kabupaten Lombok Barat Tentang RTRW Kabupaten Lombok Barat Tahun 2011-2031.

[57]Peraturan Daerah Kabupaten Lombok Utara Nomor 9 Tahun 2011 Tentang RTRW Kabupaten Lombok Utara Tahun 2011 2031.

[58]Peraturan Daerah Kabupaten Lombok Tengah Nomor 7 Tahun 2011 Tentang RTRW Kabupaten Lombok Tengah Tahun 2011-2031.

[59]Peraturan Pemerintah Republik Indonesia Nomer 26 Tahun 2008 tentang Rncana tata Ruang Nasional.

[60]Renstra Dinas Pariwisata Provinsi NTB, 2013-2018

[61] Surat Keputusa Mentri Kehutanan RI Nomor 298 / MEN HUT II / 2005 Tentang Penetapan Kawasan Taman Nasional Gunung Rinjani.

[62] Undang - Undang Nomor 23 Tahun 2014 Tentang Pemerintahan Daerah

[63]Guntara. 2013. Pengertian Overlay Dalam Informasi Geografi. Sumber : https://www.guntara.com/2013/01/pengertia n-overlay-dalam-sistem.html

[64]Pemerintah NTB. 2019. Jumlah Angkatan Kerja di Provinsi NTB Tahun 2016. Sumber: http://www.ntb.bps.go.id

[65]Pemerintah NTB. 2019. Jumlah Kunjungan Wisatwan Provinsi NTB Tahun 2014-2016. Sumber: http://www.ntb.bps.go.id

[66]Pemerintah NTB. 2019. Jumlah Penduduk Menurut Jenis Kelamin dan Kabupaten/Kota Tahun $2017 . \quad$ Sumber: http://www.ntb.bps.go.id

[67]Pemerintah NTB. 2019. Tingkat Pendidikan Berdasarkan Kabupaten/Kota di Provinsi NTB Tahun 2010-2014. Sumber: http://www.ntb.bps.go.id 
HALAMAN INI SENGAJA DIKOSONGKAN 